\title{
Linked, if Not the Same, Mi-1 Homologues Confer Resistance to Tomato Powdery Mildew and Root-Knot Nematodes
}

\author{
Alireza Seifi, ${ }^{1}$ Isgouhi Kaloshian, ${ }^{2}$ Jack Vossen, ${ }^{1}$ Daidi Che, ${ }^{3}$ Kishor K. Bhattarai, ${ }^{2}$ Junmei Fan, ${ }^{1}$ Zabun \\ Naher, ${ }^{1}$ Aska Goverse,${ }^{4}$ W. Freddy Tjallingii, ${ }^{5}$ Pim Lindhout, ${ }^{1}$ Richard G. F. Visser, ${ }^{1,6}$ and Yuling Bai ${ }^{1,6}$ \\ ${ }^{1}$ Wageningen UR Plant Breeding, Wageningen University and Research Center, Droevendaalsesteeg 1, 6708PB \\ Wageningen, The Netherlands; ${ }^{2}$ Department of Nematology, University of California, Riverside 92521, U.S.A.; ${ }^{3}$ Horticulture \\ College of Northeast Agricultural University, Haerbin 150030, China; ${ }^{4}$ Laboratory of Nematology, Wageningen University, \\ Droevendaalsesteeg 1, 6708PB Wageningen, The Netherlands; ${ }^{5}$ Laboratory of Entomology, Wageningen University, and \\ EPG systems, Dillenburg 12, 6703CJ Wageningen, The Netherlands; ${ }^{6}$ Centre for BioSystems Genomics, The Netherlands \\ Genomics Initiative/Netherlands Organization for Scientific Research, PO Box 98, 6700AA Wageningen, The Netherlands
}

Submitted 30 June 2010. Accepted 13 December 2010.

\begin{abstract}
On the short arm of tomato chromosome 6, a cluster of disease resistance $(R)$ genes have evolved harboring the $M i-1$ and $C f$ genes. The $M i-1$ gene confers resistance to root-knot nematodes, aphids, and whiteflies. Previously, we mapped two genes, $\mathrm{Ol}-4$ and $\mathrm{Ol}-6$, for resistance to tomato powdery mildew in this cluster. The aim of this study was to investigate whether $\mathrm{Ol}-4$ and $\mathrm{Ol}-6$ are homologues of the $\boldsymbol{R}$ genes located in this cluster. We show that near-isogenic lines (NIL) harboring Ol-4 (NIL-Ol-4) and Ol-6 (NIL-Ol-6) are also resistant to nematodes and aphids. Genetically, the resistance to nematodes cosegregates with $\mathrm{Ol}-4$ and $\mathrm{Ol}-6$, which are further fine-mapped to the $M i-1$ cluster. We provide evidence that the composition of Mi-1 homologues in NIL-Ol-4 and NIL-Ol-6 is different from other nematode-resistant tomato lines, Motelle and VFNT, harboring the $M i-1$ gene. Furthermore, we demonstrate that the resistance to both nematodes and tomato powdery mildew in these two NIL is governed by linked (if not the same) $\mathrm{Mi}-1$ homologues in the $\mathrm{Mi}-1$ gene cluster. Finally, we discuss how Solanum crops exploit $M i-1$ homologues to defend themselves against distinct pathogens.
\end{abstract}

A cluster of disease resistance $(R)$ genes has evolved on the short arm of tomato (Solanum lycopersicum) chromosome 6 (Fig. 1), which harbors $R$ genes ( $C f-2, C f-5$, and $M i-1)$ that mediate resistance to distinct pathogens. $C f-2$ (originating from $S$. pimpinellifolium) and $C f-5$ (found in $S$. lycopersicum var. cerasiforme) confer resistance to the fungus Cladosporium fulvum. $M i-1$ (originating from $S$. peruvianum) mediates resistance to three very different organisms: root-knot nematodes (Meloidogyne incognita, $M$. arenaria and $M$. javanica; hereafter refer to as Meloidogyne spp.), aphids (Macrosiphum euphorbiae), and whiteflies (Bemisia tabaci) (Dickinson et al. 1993; Kaloshian et al. 1998). Mi-l belongs to the largest class of $R$

Corresponding author: Y. Bai; E-mail: bai.yuling@wur.nl

This article is in the public domain and not copyrightable. It may be freely reprinted with customary crediting of the source. The American Phytopathological Society, 2011. genes that encodes a protein containing a nucleotide-binding site plus leucine-rich repeats (NBS-LRRs) (Milligan et al. 1998). $C f-2$ and $C f-5$ encode receptor-like proteins with LRR and transmembrane domains (Dixon et al. 1996). Cloning of these $R$ genes uncovered the presence of seven $\mathrm{Mi}-1$ homologues (Seah et al. 2007), three $C f-2$ homologues (Dixon et al. 1996), and four $C f-5$ homologues (Dixon et al. 1998) in this $R$ gene cluster. The cluster of $M i-1$ homologues spans approximately $430 \mathrm{~kb}$ (Fig. 1B) and consists of two pseudogenes, one truncated gene, and four intact genes (Seah et al. 2007). Among these seven $\mathrm{Mi}-\mathrm{I}$ homologues, only $\mathrm{Mi}-1.2$ has been shown to be functional and confer resistance to nematodes (Milligan et al. 1998), aphids (Rossi et al. 1998), and whiteflies (Nombela et al. 2003).

In addition to the cloned $C f$ and $M i-1$ genes, Mi-9 (Ammiraju et al. 2003), Ty-1 (a locus for resistance to Tomato yellow leaf curling virus [TYLCV]), and Cm6.1 (Zhang et al. 2002) have been mapped in the $M i-1$ cluster (Ammiraju et al. 2003; Zhang et al. 2002). Interestingly, $M i-9$ in tomato has been shown to be an $M i-1$ homologue (Jablonska et al. 2007). In addition, $M i-1$ homologues have been identified at syntenic positions in other solanaceous crops. For example, the potato Rpi-blb2 gene conferring late blight resistance is an Mi-1 homologue on the short arm of potato chromosome 6 (Vossen et al. 2005). It is intriguing to investigate whether other resistance genes mapped in this cluster are also homologues of $\mathrm{Mi}$ 1 or $C f$ genes.

Previously, we mapped two resistance genes-Ol-4, originating from $S$. peruvianum LA2172, and Ol-6, with unknown origin - on the short arm of tomato chromosome 6 in the $\mathrm{Mi}$ 1 cluster. These $O l$ genes confer resistance to the fungus Oidium neolycopersici, causal agent of tomato powdery mildew, by triggering the hypersensitive response (HR) (Bai et al. 2005). In this study, we show that near-isogenic lines (NIL) harboring $\mathrm{Ol}-4$ and $\mathrm{Ol}-6$ are resistant to $O$. neolycopersici, M. incognita, and Macrosiphum euphorbiae but not to TYLCV or C. fulvum. We provide the evidence that resistance to nematodes cosegregates with $\mathrm{Ol}-4$ and $\mathrm{Ol}-6$. Further, we demonstrate that silencing $M i-1$ homologues in these NIL compromises the resistance to both $O$. neolycopersici and $M$. incognita, suggesting that $\mathrm{Ol}-4$ and $\mathrm{Ol}-6$ are $\mathrm{Mi}-\mathrm{I}$ homologues and the resistance to nematodes in these two NIL is also controlled by $M i-1$ homologues. 


\section{RESULTS}

\section{NIL-Ol-4 and NIL-Ol-6 are resistant to $O$. neolycopersici,} nematodes, and aphids.

Two NIL were generated with an introgression on the short arm of tomato chromosome 6 that contains either $\mathrm{Ol}-4$ (NILOl-4) or Ol-6 (NIL-Ol-6) in the genetic background of S. lycopersicum cv. Moneymaker (MM) (Bai et al. 2005). In these two NIL, the introgression resides only on the short arm, including at least the chromosomal region between markers T1198 and cLET-2-H1 (Fig. 1A), which embraces the Mi-1 gene cluster harboring $M i-1, C f-2$, and $C f-5$. In addition, $T y-1$ is also mapped in this cluster (Zamir et al. 1994). To test whether NIL-Ol-4 and NIL-Ol-6 have functional alleles of these $R$ genes, these two NIL were challenged with the corresponding pathogens: M. incognita, Macrosiphum euphorbiae,
C. fulvum (race 2, 5, and 2.4.5), and one TYLCV strain. In the disease assays with $C$. fulvum and TYLCV, the susceptible control MM as well as NIL-Ol-4 and NIL-Ol-6 were equally susceptible to the three races of $C$. fulvum and TYLCV, except for an intermediate level of resistance to race 5 of $C$. fulvum in NIL-Ol-6 (Table 1; Fig. 2). Because $C$. fulvum race 5 contains $A v r 2$, the intermediate level of resistance in NIL-Ol-6 might imply that the allele of $C f-2$ in NIL-Ol-6 is functional to confer a certain level of resistance.

As to nematode resistance, NIL-Ol-4 and NIL-Ol-6 were as resistant as Motelle, the resistant control which contains the $M i-1.2$ functional homologue of the $M i-1$ gene originating from $S$. peruvianum PI 128657. No galls or egg masses were observed on the roots of NIL-Ol-4 and NIL-Ol-6 plants in contrast to more than 50 egg masses observed on the roots of MM plants. As to the aphid assay, MM and Motelle were used as

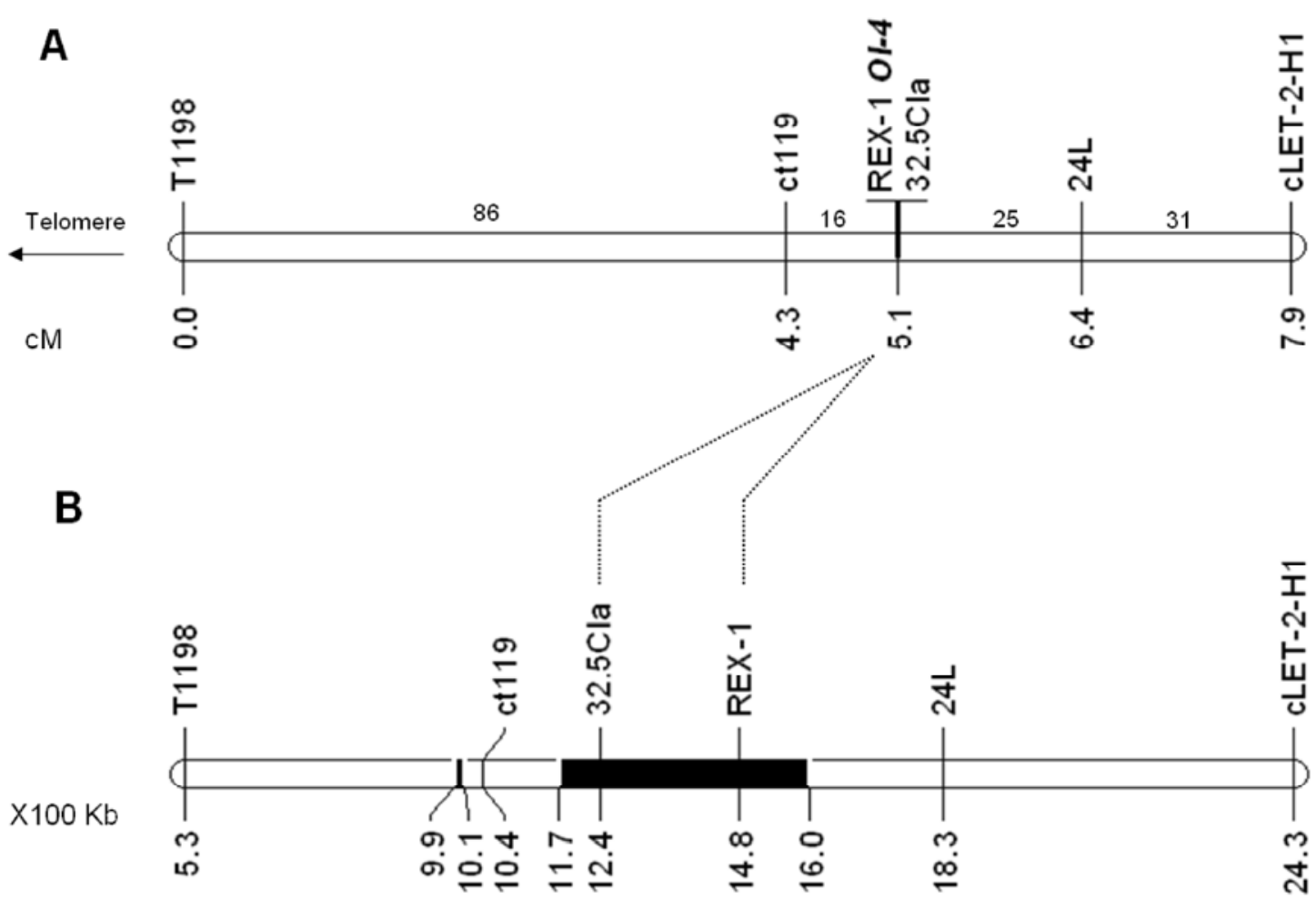

Fig. 1. Genetic and physical maps showing the part of the short arm of tomato chromosome 6 which harbors the $M i-1$ gene cluster. The introgression in nearisogenic lines (NIL)-Ol-4 and NIL-Ol-6 is defined on the short arm covering at least the chromosomal region between markers T1198 and cLET-2-H1. A, Genetic map was based on recombinant screening for the Ol-4 gene by using a $\mathrm{BC}_{3} \mathrm{~S}_{1}$ population derived from interspecific crosses of Solanum lycopersicum cv. Moneymaker with S. peruvianum LA2172. Genetic distances (centimorgans [cM]) are shown in the lower part, while the number of recombinants obtained in each marker interval is mentioned in the interval. B, Physical map of the same region in tomato (S. lycopersicum) based on whole-genome shotgun sequencing release 1.05 (Sol Genomics Network website). Distances in 100-kb scale are shown in the lower part. The segment spanning the Mi-1 gene cluster is shown in solid black (1,170 to 1,600 kb) as well as the $C f$ gene cluster which is located above ct119 (990 to $1,010 \mathrm{~kb})$.

Table 1. Qualitative evaluation of responses of different tomato lines to the tested pathogens and pests ${ }^{\mathrm{a}}$

\begin{tabular}{|c|c|c|c|c|c|c|}
\hline \multirow[b]{2}{*}{ Lines } & \multirow[b]{2}{*}{ Oidium neolycopersici } & \multirow[b]{2}{*}{ Meloidogyne incognita } & \multirow[b]{2}{*}{ TYLCV } & \multicolumn{3}{|c|}{ Cladosporium fulvum race } \\
\hline & & & & 2 & 5 & 2.4 .5 \\
\hline Moneymaker & $\mathrm{S}$ & $\mathrm{S}$ & $\mathrm{S}$ & $\mathrm{S}$ & $\mathrm{S}$ & $\mathrm{S}$ \\
\hline NIL-Ol-4 & $\mathrm{R}$ & $\mathrm{R}$ & $\mathrm{S}$ & $\mathrm{S}$ & $\mathrm{S}$ & $\mathrm{S}$ \\
\hline NIL-Ol-6 & $\mathrm{R}$ & $\mathrm{R}$ & $\mathrm{S}$ & $\mathrm{S}$ & IR & $\mathrm{S}$ \\
\hline Resistant controls & $\mathrm{R}$ & $\mathrm{R}$ & $\mathrm{R}$ & $\mathrm{R}$ & $\mathrm{R}$ & $\mathrm{R}$ \\
\hline Plants tested per line & 20 & 20 & 20 & 10 & 10 & 10 \\
\hline
\end{tabular}

a TYLCV = Tomato yellow leaf curling virus; R stands for resistant, $\mathrm{S}$ for susceptible, and IR for intermediate resistant. For disease tests with $O$. neolycopersici and $C$. fulvum, plants with no fungal sporulation were regarded as $\mathrm{R}$, plants with heavy sporulation as $\mathrm{S}$, and plants with weak fungal sporulation as IR. For the disease assay with $M$. incognita, plants were scored as resistant if the number of egg masses was less than $10 \%$ of the egg masses on the susceptible control Moneymaker. For the TYLCV test, plants showing symptoms such as curling and yellowing of young leaves (resulting sometimes in stopping of growth) were scored as S and plants without any symptom as R. Resistant control for the $M$. incognita disease test was Motelle, a cultivar carrying the Mi-1 gene. In the disease test with TYLCV, we used a breeding line carrying the $T y-1$ gene as a resistant control. A commercial hybrid, Tradiro, was the resistant control in the C. fulvum disease test. 
susceptible and resistant controls, respectively. Seven days after confining aphids on the plants with clip cages, the number of adult aphids was similar among the lines. However, the number of nymphs was significantly less on Motelle than that on other lines (Fig. 3A). After the second 7 days, comparable numbers of adult aphids were found on Motelle and NIL-Ol-4, which were significantly lower than that on NIL-Ol-6 and MM (Fig. 3B). Though the number of adults and nymphs on NILOl-6 was not as low as that on NIL-Ol-4 and Motelle, it was still significantly lower than that on MM. Similar results were obtained in another aphid assay without using clip cages (Fig. 3C). Furthermore, an electrical penetration graph (EPG) (Tjallingii 1988) was applied to monitor the feeding behavior of aphids as a different method for aphid assay. The proportion of time (recorded in seconds) that aphids spent ingesting the phloem sap on MM, NIL-Ol-4, NIL-Ol-6, and Motelle was 10,227, 4,737, 9,534, and 4,324 s, respectively. Comparisons with MM, Motelle, and NIL-Ol-4 but not NIL-Ol-6 showed significant reduction in the proportion of time. Although NILOl-4 and Motelle showed a comparable level of resistance, substantial differences were observed between these two lines in the performance test (Fig. 3A). Thus, the performance and feeding behavior of aphids showed that these two NIL were not as resistant as Motelle, suggesting that either the allele of Mi-1.2 in these two NIL is not as strong as the allele in Motelle or another $M i-1$ homologue (rather than $M i-1.2$ ) is involved in response to aphids in these two NIL.

\section{The composition of $\mathrm{Mi}-1$ homologues in NIL-Ol-4 and NIL-Ol-6 is different from other nematode-resistant tomato lines.}

The size and sequence of the first intron of $M i-1$ is variable among $M i-1$ homologues and has been used to differentiate $M i-1.2$ from other $M i-1$ homologues (Seah et al. 2007). To check the presence or absence of $M i-1.2$ in NIL-Ol-4 and NILOl-6, the first intron of $M i-1$ homologues was amplified in these two NIL. The size of the three easily discernable amplified introns from NIL-Ol-4 and NIL-Ol-6 appeared to be different from those amplified in MM and Motelle (harboring the functional $M i-1.2$ homologue of the $M i-1$ gene) (Fig. 4A). Furthermore, we sequenced the amplified intron fragments from these NIL and performed sequence alignment along with available $M i-1$ first intron sequences from VFNT cherry tomato (carrying the Mi-1.2 homologue and, therefore, nematoderesistant) (Seah et al. 2004), S. arcanum LA2157 (donor of the nematode resistance gene $\mathrm{Mi}-9$ ), and LA392 (nematode susceptible) (Jablonska et al. 2007). The introns of these two
NIL were different from the Mi-1.2 intron and formed two clades which were clearly distinct from other clades derived from VFNT, $S$. arcanum LA2157, and LA392 (Fig. 4B). Thus, we conclude that the $M i-1.2$ allele of the $M i-1$ gene is not present in NIL-Ol-4 and NIL-Ol-6. Furthermore, the intron sequences were not exactly the same in NIL-Ol-4 and NIL-Ol-6, implying that these two NIL have introgressions from different donors.

\section{Resistances to root-knot nematodes and powdery mildew co-segregate.}

Thus far, genes conferring resistance to root-knot nematodes in tomato have been mapped on both chromosome 6 and 12 . Though we were sure that NIL-Ol-4 and NIL-Ol-6 have introgression on tomato chromosome 6 , we could not exclude the possibility that they also contain introgressions on chromosome 12 . To verify whether genes for nematode resistance in these two NIL are located on chromosome 6 , two $\mathrm{BC}_{3} \mathrm{~S}_{1}$ populations (80 individuals each) segregating for $\mathrm{Ol}-4$ and $\mathrm{Ol}-6$ were tested for response to both $O$. neolycopersici and $M$. incognita. By making cuttings, two disease tests were performed on the same individual plant (see Materials and Methods). The nematode resistance segregated in both populations following a resistant/susceptible (R:S) ratio of 3R:1S (58R:22S with $\chi^{2}=$ 0.27 for the $0 l-4$ population, and $64 \mathrm{R}: 16 \mathrm{~S}$ with $\chi^{2}=1.07$ for the $\mathrm{Ol}-6$ population). In addition, the nematode resistance in these two populations fully cosegregated with the resistance to $O$. neolycopersici as well as markers linked to $\mathrm{Ol}-4$ and $\mathrm{Ol}-6$ loci (Table 2; Fig. 1A). These results raised the possibility that $O l-4$ and $O l-6$ govern resistance to both nematodes and $O$. neolycopersici or that genes conferring nematode resistance in these NIL are linked to $\mathrm{Ol}-4$ and $\mathrm{Ol}-6$.

\section{$\mathrm{Ol}-4$ is located in the $\mathrm{Mi}-\mathrm{I}$ gene cluster.}

Previously, our mapping results suggested that $\mathrm{Ol}-4$ and $\mathrm{Ol}$ 6 are likely allelic variants of the same gene (Bai et al. 2005). Therefore, we performed fine-mapping only for the $\mathrm{Ol}-4$ gene. A recombinant screening was carried out in a $\mathrm{BC}_{2} \mathrm{~S}_{1}$ population by using markers located on the short arm of chromosome 6 (Table 2; Fig. 1A). From 2,000 plants screened, more than 16 recombinants were found between the $\mathrm{Ol}-4$ locus and ct119 marker that is tightly linked to the $C f$ gene cluster (Fig. 1A), suggesting that $\mathrm{Ol}-4$ is not located in this cluster. No recombination events occurred between $\mathrm{Ol}-4$ and an interval flanked by markers $32.5 \mathrm{Cla}$ and $\mathrm{REX}-1$, where the $M i-1$ gene is located (Fig. 1A), showing that $\mathrm{Ol}-4$ is located in the $\mathrm{Mi}-1$ gene cluster.

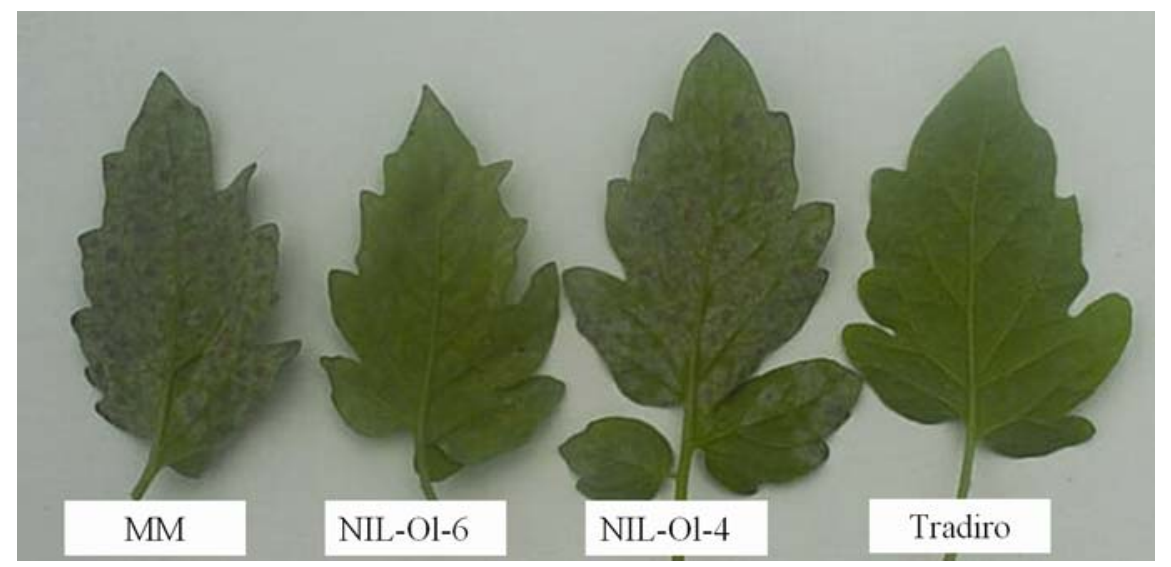

Fig. 2. Abaxial side of leaves of different tomato lines inoculated with Cladosporium fulvum race 5. No symptoms of fungal infection were visible on the resistant control Tradiro, whereas heavy sporulation was detected on susceptible control Moneymaker (MM) and near-isogenic line (NIL)-Ol-4. Slight fungal sporulation was visible on NIL-Ol-6, suggesting an intermediate level of resistance in this line. 


\section{$\mathrm{Ol}-4$ and $\mathrm{Ol-6}$ are homologues of $\mathrm{Mi}-1$.}

In addition to seven $M i-1$ homologues, several other genes, including transport inhibitor response-1 (TIR-1), jumonji transcription factors, $\mathrm{Na}+\mathrm{H}+$ antiporter, transposase, and genes with unknown function, are present in the $M i-1$ gene cluster (Seah et al. 2007). Considering that $\mathrm{Ol}-4$ and $\mathrm{Ol}-6$ are located in the $M i-1$ gene cluster, the first possibility would be that the $\mathrm{Ol}-4$ and $\mathrm{Ol}-6$ genes are $\mathrm{Mi}-\mathrm{l}$ homologues. To test this possibility, transient silencing of $M i-1$ homologues was carried out through virus-induced gene silencing (VIGS). A conserved domain of $M i-1$ homologues was used for VIGS, which had been utilized previously to silence successfully all the $M i-1$ homo-
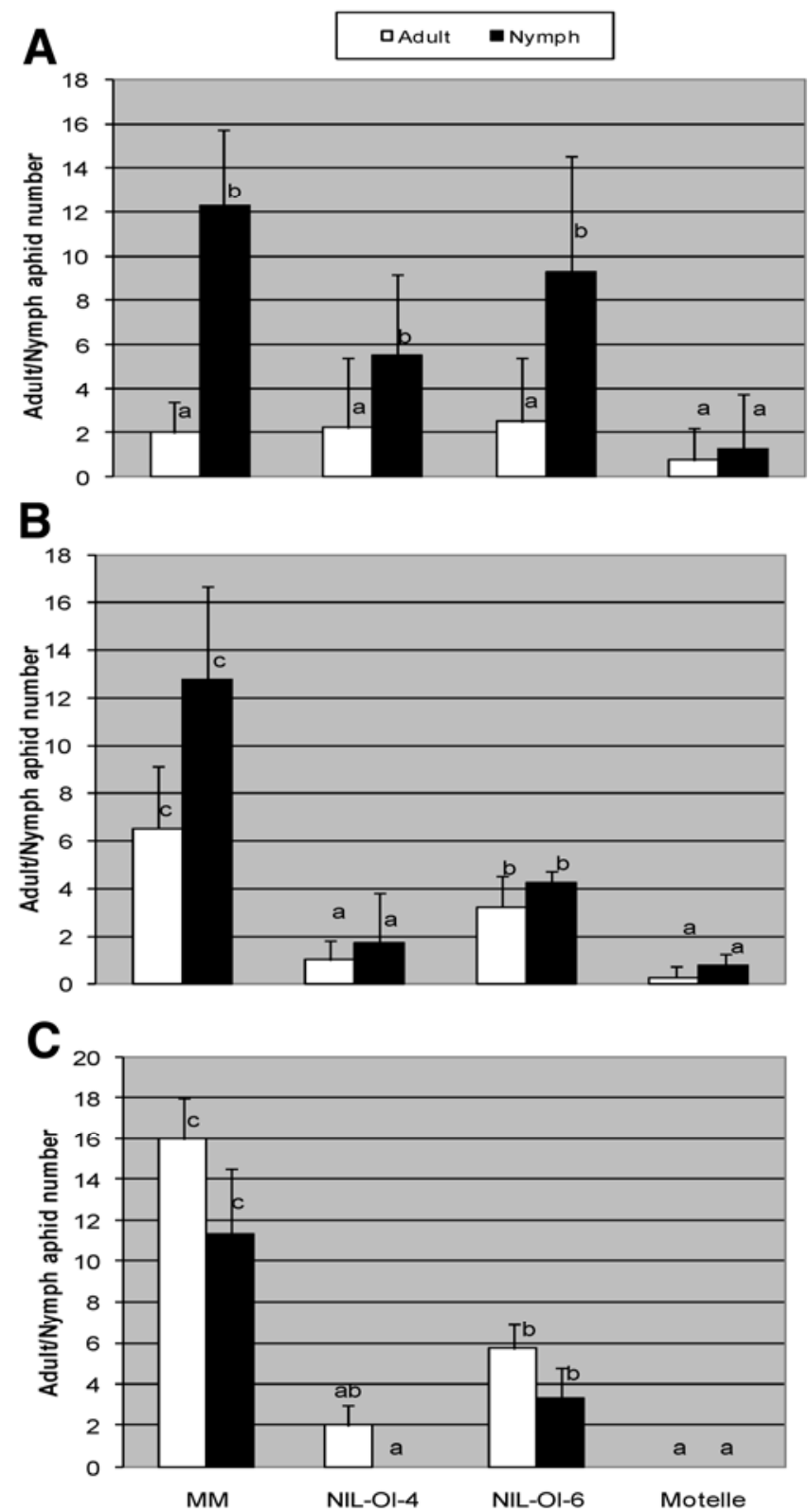

Fig. 3. Aphid tests on near-isogenic lines (NIL)-Ol-4 and NIL-Ol-6 compared with Moneymaker (MM; susceptible control) and Motelle (resistant control). Mean value per line is presented and means with a different letter show significance at $5 \%$ level $(P<0.05)$. $\mathbf{A}$ and $\mathbf{B}$, Performance of aphids within clip cages. On each plant (four plant per line in total), 10 aphids were mounted with a clip cage. After 7 days, the number of aphids (adults and nymphs) was counted and then adults were removed. Seven days later (14-day time point) counting was repeated. C, Performance of aphids without clip cage. Data were collected 10 days after placing 10 aphids on the abaxial leaf surface of each plant (three plants per line). logues on tomato chromosome 6 (Jablonska et al. 2007; Li et al. 2006). Upon inoculation with $O$. neolycopersici, all MM plants infiltrated with the empty vector showed heavy fungal sporulation, suggesting that VIGS did not influence the susceptibility of tomato to $O$. neolycopersici (Fig. 5A). No fungal sporulation was observed on NIL-Ol-4 and NIL-Ol-6 plants infiltrated with the empty vector (Fig. 5A). In contrast, clear fungal sporulation was observed on plants which were infiltrated with the Mi-l silencing construct (Fig. 5A). We extracted RNA from the leaves of these infected plants and monitored the $M i-1$ homologues transcript level. In these $M i$-silenced plants, up to a fourfold reduction of $M i-1$ transcript level was detected by quantitative reverse-transcription polymerase chain reaction (PCR) (Fig. 5B). Similar results were obtained in three independent experiments. Thus, silencing $M i-1$ homologues compromised resistance to $O$. neolycopersici in NILOl-4 and NIL-Ol-6, demonstrating that at least one of the $\mathrm{Mi}-1$ homologues in the $\mathrm{Mi}-1$ gene cluster is required for resistance to $O$. neolycopersici.

The same $M i$-1-silencing constructs were used to infiltrate another set of MM, NIL-Ol-4, and NIL-Ol-6 plants to test whether silencing $\mathrm{Mi}-1$ homologues could also compromise resistance to root-knot nematodes in these NIL. More than 200 egg masses appeared on the roots of the susceptible MM plants and almost no egg masses on the roots of the two resistant NIL infiltrated with the empty vector (Fig. 6). However, half of the $M i$-silenced NIL plants showed egg masses: 10 to 50 for NILOl-4 and 10 to 100 for NIL-Ol-6 (Fig. 6). Because the nematode resistance in these two NIL is complete, the presence of more than 10 egg masses was a clear indication that resistance was compromised by silencing $\mathrm{Mi}-\mathrm{l}$ homologues. Thus, resistance to both $O$. neolycopersici and root-knot nematodes in these two NIL is conferred by $M i-1$ homologues.

\section{DISCUSSION}

Mapping of the tomato genes $\mathrm{Ol}-4$ and $\mathrm{Ol}-6$ in the $\mathrm{Mi}-\mathrm{I}$ gene cluster and cosegregation of resistance to tomato powdery mildew with resistance to root-knot nematodes put forward the hypothesis that $\mathrm{Ol}-4$ and $\mathrm{Ol}-6$ are homologues of the $\mathrm{Mi}-1$ gene. Indeed, transient silencing of $\mathrm{Mi}-\mathrm{I}$ homologues on tomato chromosome 6 compromised both powdery mildew (Fig. 5) and nematode (Fig. 6) resistance in NIL-Ol-4 and NIL-Ol-6, supporting our hypothesis. Analysis of the first intron of $M i-1$ homologues showed that the composition of the Mi-1 gene cluster in NIL-Ol-4 and NIL-Ol-6 is different from the cluster in MM (nematode susceptible), Motelle, and VFTN (nematode resistant) (Fig. 4). This difference in the $M i-1$ gene cluster was also reflected by the response of NIL-Ol-4 and NIL-Ol-6 to aphids (Macrosiphum euphorbiae). These two lines were not as resistant as Motelle (Fig. 3). It is worthwhile to mention that the aphid clone (the same clone used by Kaloshian and associates [1998]) was not very well adapted to MM in this study when clip cages were applied (Fig. 3A and B). A high number of adult aphids were observed without using clip cages (Fig. 3C). Nevertheless, performance and multiple EPG showed distinct differences between plant genotypes. Therefore, we conclude that the $M i-1.2$ allele in NIL-Ol4 and NIL-Ol-6 is different from that in Motelle.

It remains to be answered whether, in NIL-Ol-4 or NIL-Ol6, the same $\mathrm{Mi}-\mathrm{l}$ homologue on the short arm of tomato chromosome 6 governs resistance to root-knot nematodes and tomato powdery mildew, and partial resistance to aphid. It has been suggested that, though many homologues of a specific $R$ gene are located in a cluster, usually only one of the homologues is functional (Michelmore and Meyers 1998). For example, in $S$. peruvianum PI 128657, the donor of the Mi-1 
gene, only one (Mi-1.2) of seven homologues has been shown to be functional and confer resistance to three different pathogens, including nematodes, aphids, and whiteflies (Williamson and Kumar 2006). Currently, we are in the progress of cloning of $\mathrm{Ol}-4$ and $\mathrm{Ol}-6$, which will reveal the identities of these two genes and also shed light on the genome structure and organization of related homologues in the $\mathrm{Mi}-1$ gene cluster.

Because the donor of the $\mathrm{Ol-6}$ gene is unknown, it is unclear whether $\mathrm{Ol}-4$ and $\mathrm{Ol}-6$ are alleles of the same $\mathrm{Mi}-\mathrm{l}$ homologue or are different homologues of $M i-1$. Though the marker pattern and resistance spectrum to $O$. neolycopersici indicate that $\mathrm{Ol}-6$ is possibly identical or allelic to $\mathrm{Ol}-4$, differences between these two genes have been observed in the level of resistance to tomato powdery mildew (Bai et al. 2005) and aphids (Fig. 3). Furthermore, the $M i-1$ first intron sequences were not exactly the same in NIL-Ol-4 and NIL-Ol-6 (Fig. 4), suggesting that the $M i-1$ gene cluster composition is different in these two lines. Therefore, we conclude that $\mathrm{Ol}-4$ and $\mathrm{Ol}-6$ are not identical but are allelic variants, although we could not exclude the possibility that they are different $M i-1$ homologues.

The Mi-l gene triggers HR to root-knot nematodes (Dropkin et al. 1969; Roberts and Thomason 1986) but not to aphids (de Ilarduya et al. 2003). Interestingly, $\mathrm{Ol}-4$ and $\mathrm{Ol}-6$ also mediate $\mathrm{HR}$ in response to powdery mildew (Bai et al. 2005; Li et al. 2007). HR is a hallmark of $R$-gene-mediated response (Nimchuk et al. 2003) to biotrophic pathogens (Glazebrook 2005). Therefore, it is not a surprise to observe HR in the resistance mediated by $M i-1$ homologues to powdery mildew and nematodes. No HR has been detected in the $M i$-1-mediated resistance to potato aphids (de Ilarduya et al. 2003). Data from previous

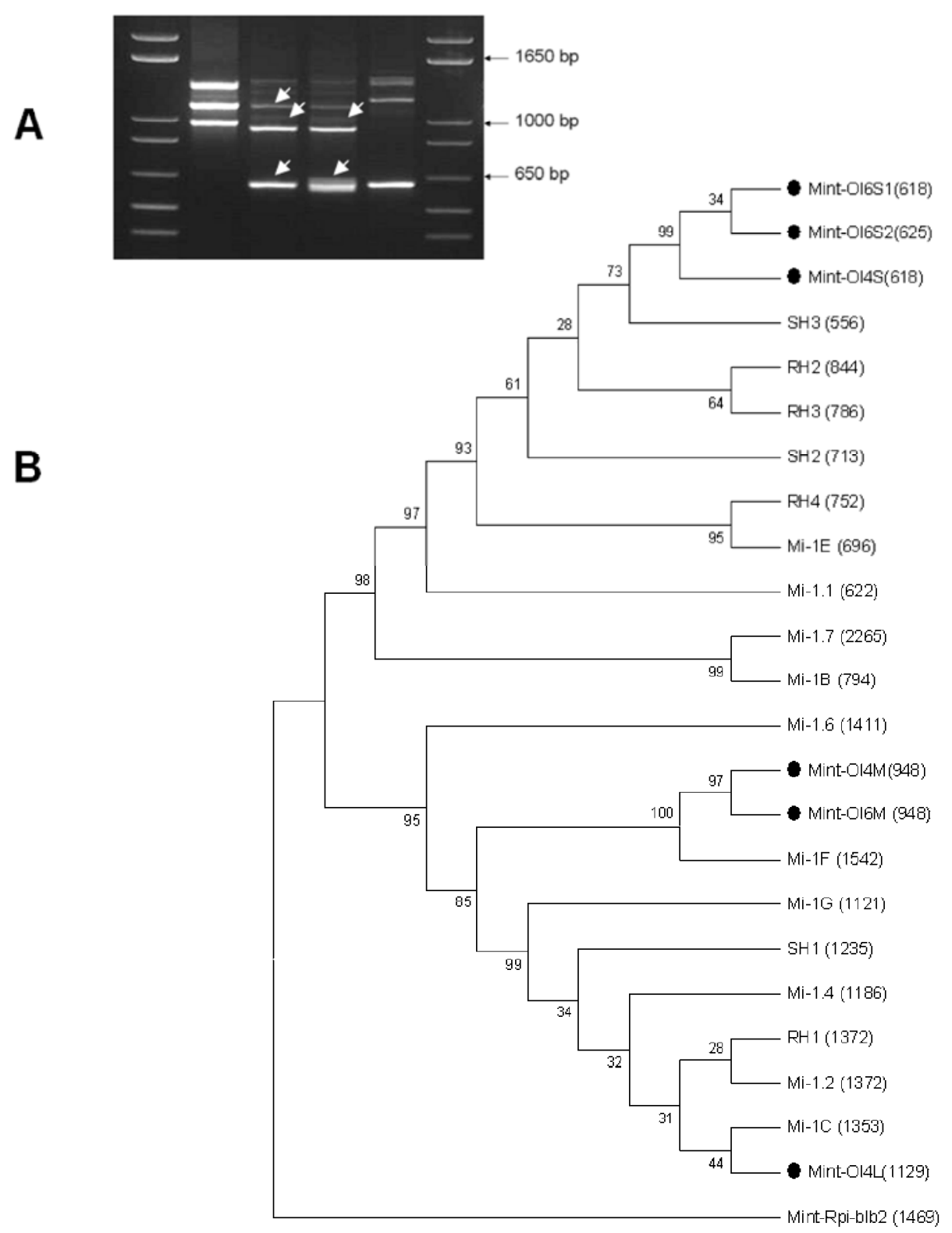

Fig. 4. Analysis of the sequence of first intron of the Mi-1 gene. A, First-intron pattern of the Mi-1 gene in Moneymaker (MM), near-isogenic lines (NIL)-Ol4, NIL-Ol-6, and Motelle (from left to right, respectively). Polymerase chain reaction fragments indicated by arrows were sequenced. B, Similarity tree was constructed based on Mi-1 first intron sequences in susceptible cv. Heinz1706 (assigned as Mi-1B, Mi-1C, Mi-1E, Mi-1F, and Mi-1G), VFNT (Mi-1.1, Mi1.2, Mi-1.4, Mi-1.6, and Mi-1.7), Solanum arcanum LA2157 (RH1, RH2, RH3, and RH4), S. arcanum LA392 (SH1-SH2, SH3, and SH4), NIL-Ol-6 (MintOl6S1, Mint-Ol6S2, and Mint-O16M), and NIL-Ol-4 (Mint-O14S, Mint-Ol-4M, and Mint-O14L). The size of each intron is mentioned in the bracket. The introns from NIL-Ol-4 and NIL-Ol-6 are indicated by dots. Bootstrap values are shown. The intron from the potato Rpi-blb2 gene (referred to as Mint-Rpiblb2) was used as the outgroup sequence. Motelle and VFNT both carry introgression from S. peruvianum PI 128657, the donor of the Mi-1 gene. Therefore, the $M i-1$ gene cluster in these two cultivars is the same. 


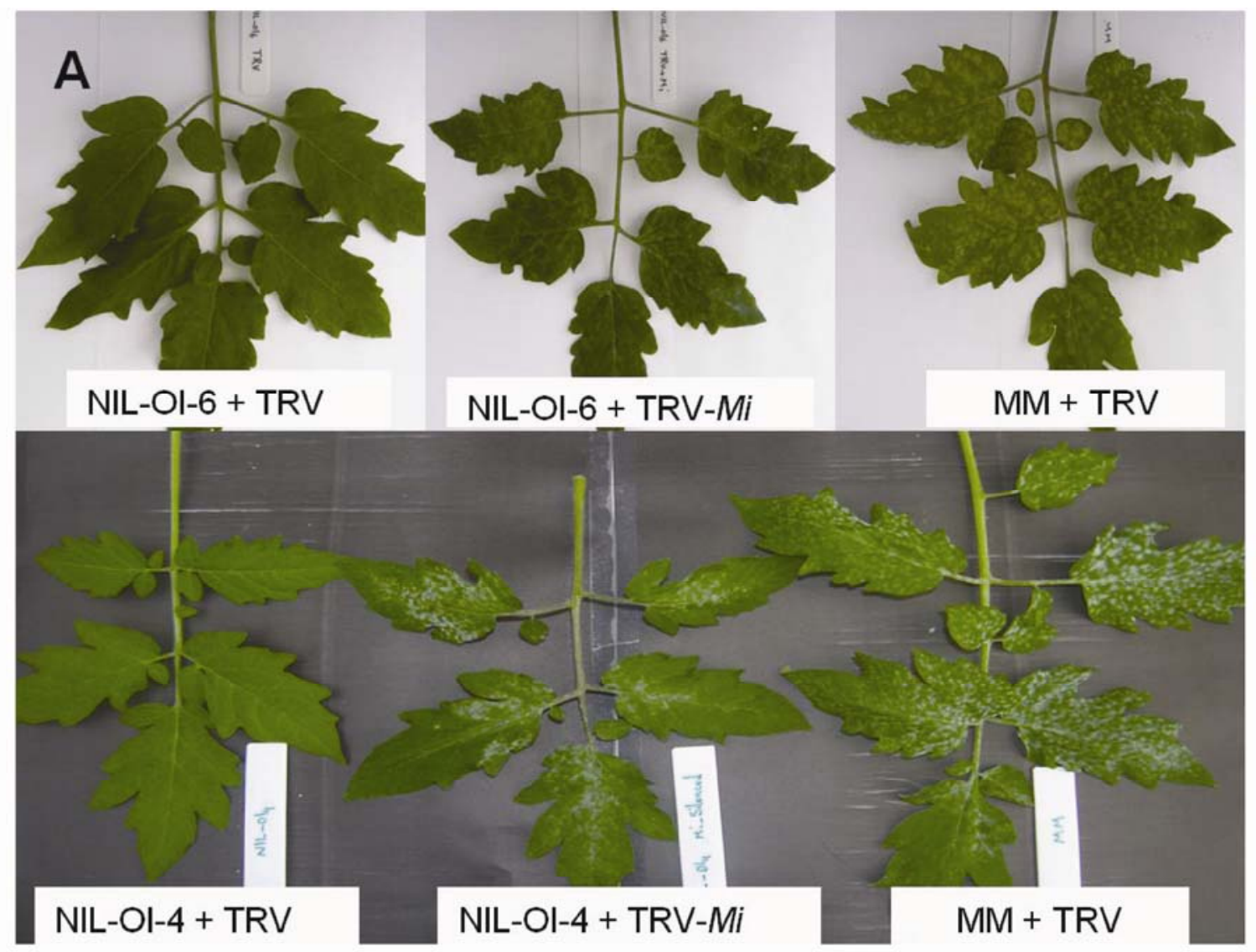

\section{B $\quad$ Relative Abundance of Mi Transcript $\mathbf{0}$ Disease Index}
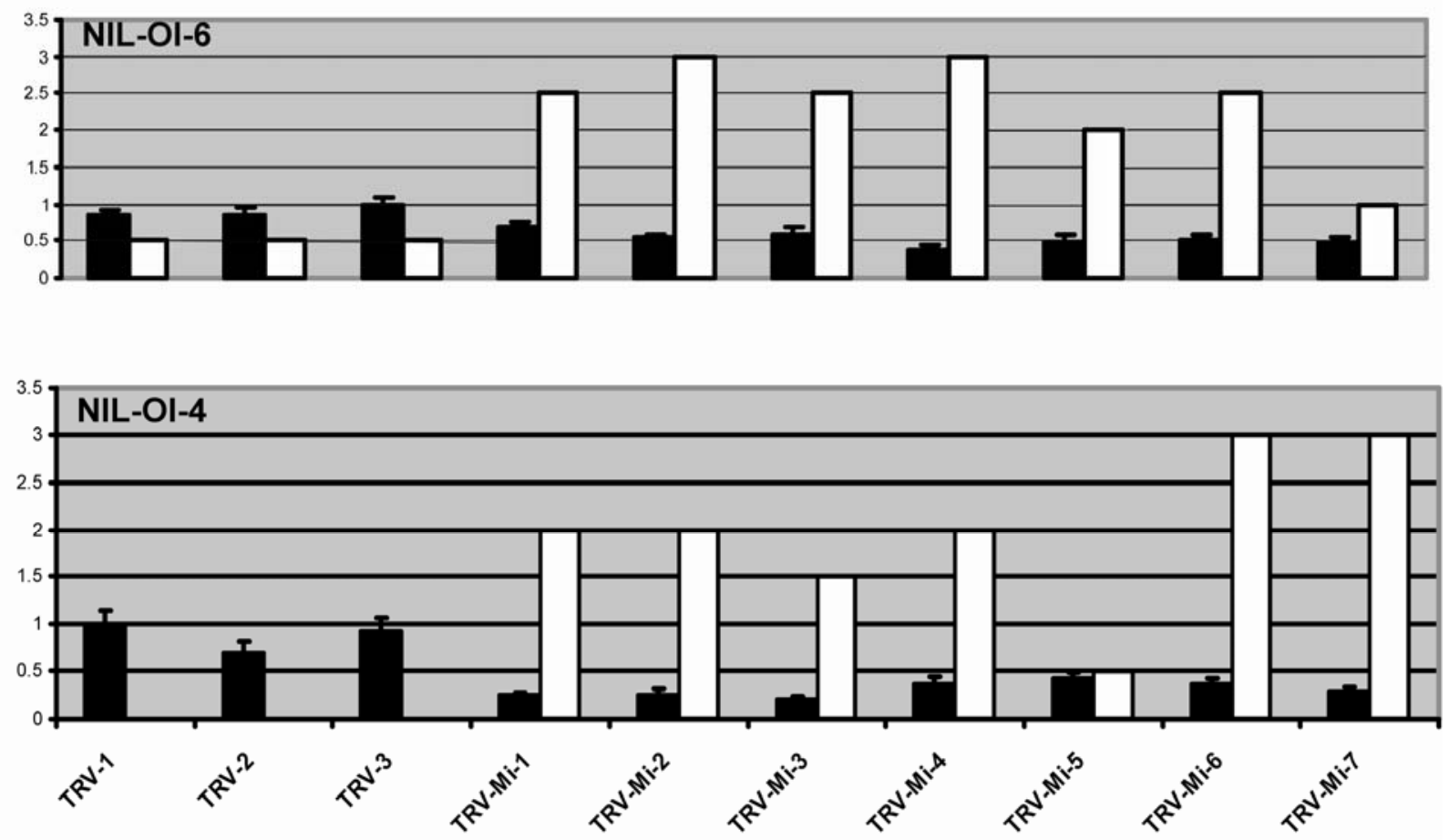

Fig. 5. Silencing of $M i$ homologues compromised resistance to Oidium neolycopersici in near-isogenic lines (NIL)-Ol-4 and NIL-Ol-6. A, NIL-Ol-4, NILOl-6, and Moneymaker (MM) were infiltrated with empty vector (TRV) or Mi-silencing constructs (TRV-Mi) that silence all seven Mi-1 homologues on tomato chromosome 6. Pictures were taken of the fourth leaves 14 days after fungal inoculation. B, Association of $M i-1$ transcript levels with $O$. neolycopersici sporulation on the same NIL-Ol-4 and NIL-Ol-6 plants. White bars show the disease index (scale from 0 to $3: 0=$ no sporulation to $3=$ heavy sporulation). Black bars show the relative abundance of the $M i-1$ transcripts as measured by the normalized fold expression of the $M i-1$ transcript. TRV plants (three replicates, TRV-1 to TRV-3) were infiltrated with an empty vector and TRV-Mi plants (seven replicates, TRV-Mi-1 to TRV-Mi-7) were infiltrated with a TRV-Mi construct. As is shown on the graph, the disease index for TRV-1 to TRV-3 is zero. 
EPG studies on feeding behavior indicated that aphids ingested only limited amounts of vascular fluids from resistant tomato plants carrying the $M i-1$ gene (Kaloshian et al. 2000). In agreement with this, our results showed that the proportion of time that aphids spent ingesting the phloem sap was significantly reduced on NIL-Ol-4 and Motelle. Further experiments are needed to study the non-HR-based mechanism associated with resistance to potato aphids mediated by different $\mathrm{Mi}-\mathrm{l}$ homologues. Moreover, the $\mathrm{Mi}-1$ gene fails to confer resistance to nematodes at higher temperatures (above $28^{\circ} \mathrm{C}$ ), which is a well-documented phenomenon for NBS-LRR proteins (Wang et al. 2009; Whitham et al. 1996; Yang and Hua 2004). Another $\mathrm{Mi}-1$ homologue, $\mathrm{Mi}-9$, that is also located in the $\mathrm{Mi}-1$ gene cluster, confers heat-stable resistance to nematodes (Jablonska et al. 2007). It would be interesting to test the heat stability of nematode resistance in NIL-Ol-4 and NIL-Ol-6.

The most intriguing question is how $\mathrm{Mi}-1$ homologues can recognize different pathogens. In addition to tomato powdery mildew, $M i-1$ homologues can confer resistance to a wide range of pathogens, including root-knot nematodes (Meloidogyne spp.), insects (Macrosiphum euphorbiae and Bemisia tabaci), and oomycetes (Phytophthora infestans). Dual or multiple specificities of $R$ genes can be explained by the guard hypothesis (Dangl and Jones 2001) that an $R$ gene guards one single virulence target which is modified by multiple effectors. Examples are Rpml in Arabidopsis (Bisgrove et al. 1994) and Pto in tomato (Kim et al. 2002) that recognize different effectors of the same bacterial pathogen. Also, the RRS1 gene in Arabidopsis confers resistance to two different pathogens (bacteria and fungus) by interacting with another $R$ gene, RPS4 (Narusaka et al. 2009). The finding that $M i-1$ homologues in Solanum spp. recognize a wide array of pathogen and pest species may suggest that they guard a common or structurally similar virulence target. On the other hand, embedding several homologues in an $R$ gene cluster could be a mechanism of making a haplotype of $R$ genes to give resistance to several dif-

Table 2. Information of polymerase chain reaction markers

\begin{tabular}{|c|c|c|c|c|}
\hline Marker & Primer sequence $\left(5^{\prime}-3^{\prime}\right)$ & Annealing temperature $\left({ }^{\circ} \mathrm{C}\right)$ & Enzyme-produced polymorphism & Reference \\
\hline T1198 & $\begin{array}{l}\text { Forward: tagtgggtatggtggctcaatg } \\
\text { Reverse: gatggcttccgatggtaggtg }\end{array}$ & 56 & $\begin{array}{l}\text { HhaI } \\
\ldots\end{array}$ & This study \\
\hline GP79L & $\begin{array}{l}\text { Forward: cactcaatgggggaagcaac } \\
\text { Reverse: aatggtaaacgagcgggact }\end{array}$ & 53 & $\begin{array}{l}\text { ApoI } \\
\ldots\end{array}$ & $\begin{array}{l}\text { Bai et al. } 2005 \\
\ldots\end{array}$ \\
\hline ct119 & $\begin{array}{l}\text { Forward: ctattctcacgtaaggggacac } \\
\text { Reverse: gtgtacatgtatgaaactctagc }\end{array}$ & 60 & $\begin{array}{l}\text { RsaI } \\
\ldots\end{array}$ & $\begin{array}{l}\text { Dixon et al. } 1995 \\
\ldots\end{array}$ \\
\hline REX-1 & $\begin{array}{l}\text { Forward: tcggagccttggtctgaatt } \\
\text { Reverse: gccagagatgattcgtgaga }\end{array}$ & $\begin{array}{l}55 \\
\ldots\end{array}$ & $\begin{array}{l}\text { TaqI } \\
\ldots\end{array}$ & Williamson et al. 1994 \\
\hline $32.5 \mathrm{Cla}$ & $\begin{array}{l}\text { Forward: acacgaaacaaagtgccaag } \\
\text { Reverse: caccaccaaacaggagtgtg }\end{array}$ & $\begin{array}{l}56 \\
\cdots\end{array}$ & $\begin{array}{l}\text { HinfI } \\
\ldots\end{array}$ & $\begin{array}{l}\text { Bai et al. } 2005 \\
\ldots\end{array}$ \\
\hline $24 \mathrm{~L}$ & $\begin{array}{l}\text { Forward: tctggggaaggtagtatgtatgc } \\
\text { Reverse: aagccgggggcgtggttc }\end{array}$ & 64 & HруCH4IV & This study \\
\hline cLET-2-H1 & $\begin{array}{l}\text { Forward:cttcttcttcttcaccetaacaca } \\
\text { Reverse: ctcgctgctgcactcgtctcttc }\end{array}$ & $\begin{array}{l}56 \\
\ldots\end{array}$ & $\begin{array}{l}\text { HpyF10VI } \\
\ldots\end{array}$ & $\begin{array}{l}\text { This study } \\
\ldots\end{array}$ \\
\hline
\end{tabular}

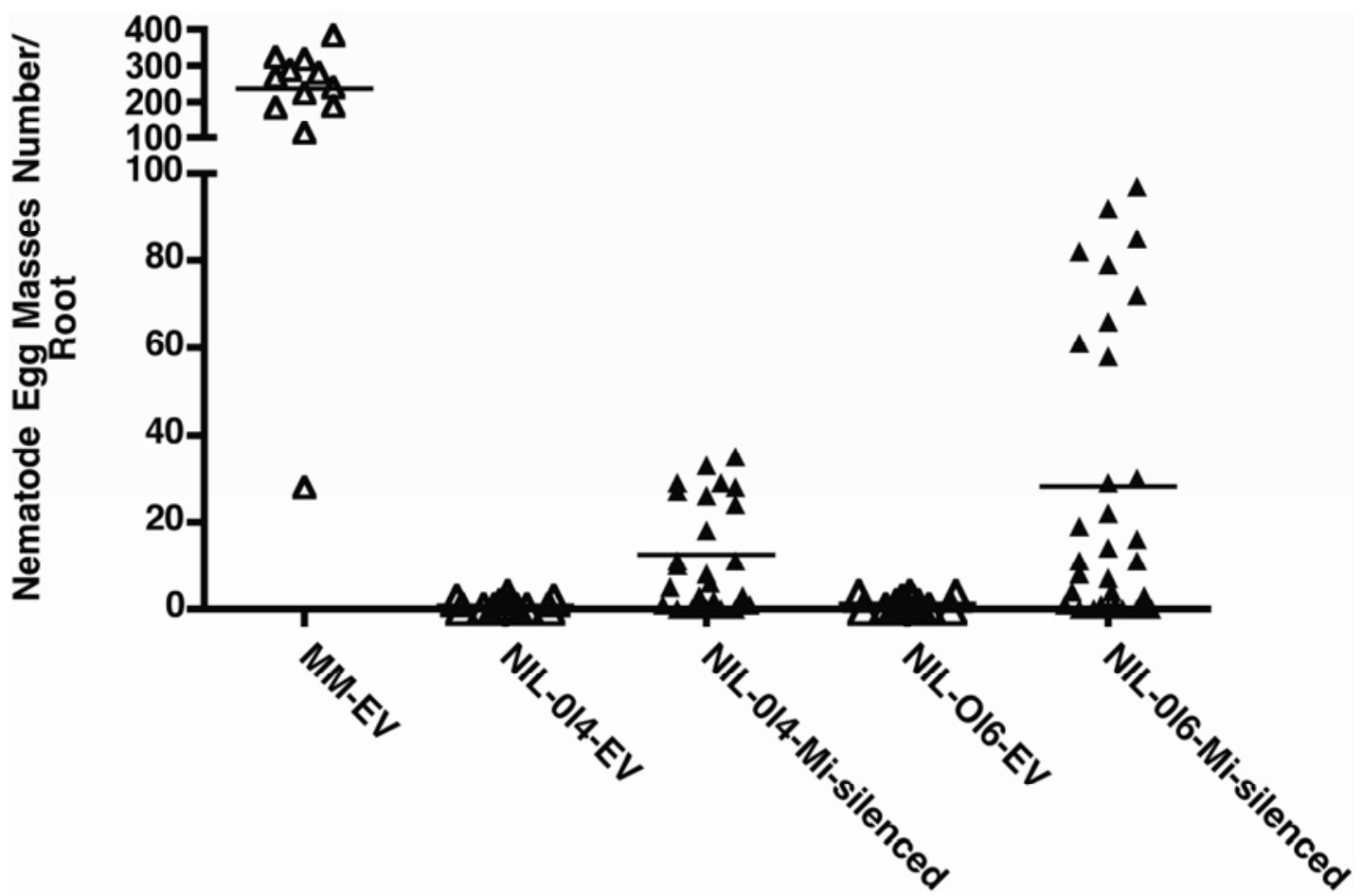

Fig. 6. Silencing Mi-1 homologues compromised resistance to Meloidogyne incognita in near-isogenic lines (NIL)-Ol-4 and NIL-Ol-6. Number of egg masses of M. incognita on the roots of NIL-Ol-4 and NIL-Ol-6 plants and susceptible control Moneymaker (MM) plants. For MM, NIL-Ol-4-Mi-silenced, NIL-Ol-6-Mi-silenced, NIL-Ol-4-EV, and NIL-Ol-6-EV, 12, 25, 30, 12, and 12 plants were tested, respectively. EV plants were infiltrated with the empty vector and Mi-silenced plants were infiltrated with a construct which silences all seven $M i$ homologues on tomato chromosome 6 . Horizontal bar indicates the mean. 
ferent pathogens simultaneously. One example is the $R x / G p a 2$ $R$ gene cluster, in which two homologues confer resistance to two distinct pathogens, a virus and a nematode (van der Vossen et al. 2000). The distinct functionality of $R$ gene homologues could be explained by amplification or reduction in the number of LRR motifs in LRR domains that could modify $R$ gene recognition specificity (Staskawicz et al. 1995). For instance, 10 of the 11 alleles that express different rust resistance specificities showed large variation in the LRR domain (Ellis et al. 1999). Comparing different $M i-1$ homologues in the $M i-1$ gene cluster revealed diversifying nucleotide changes in the LRR domain of these homologues (Seah et al. 2007), which supports the possibility that different homologues in the Mi-1 cluster could be involved in recognition of different effectors. Isolation and functional characterization of pathogen effectors or their virulence targets interacting with homologues of the $M i-1$ gene family in Solanum spp. will deepen our understanding on how Solanum crops exploit $\mathrm{Mi}-1$ homologues to defend themselves against distinct pathogens.

\section{MATERIALS AND METHODS}

\section{Plant material.}

Plant material used for mapping and disease tests were described previously (Bai et al. 2005). In short, backcross selfing populations $\left(\mathrm{BC}_{2} \mathrm{~S}_{1}\right.$ and $\left.\mathrm{BC}_{3} \mathrm{~S}_{1}\right)$ and NIL harboring Ol-4 and Ol-6 (NIL-Ol-4 and NIL-Ol-6) were derived from interspecific crosses of $S$. lycopersicum MM with S. peruvianum LA2172 and an advanced breeding line, respectively. MM was used as the recurrent parent. Motelle, harboring the $\mathrm{Mi}-1$ gene introgressed from S. peruvianum PI128657 (Ho et al. 1992), was kindly provided by the Laboratory of Cell Biology of Wageningen University, the Netherlands.

\section{Disease test.}

Leaf mold assay. Plants were inoculated with $C$. fulvum isolate 2 (containing Avr4, 5, and 9), isolate 5 (containing Avr2, 4, and 9), and isolate 2.4.5 (containing Avr9). MM was used as susceptible control and the commercial hybrid Tradiro (resistant to these three races) as resistant control. Leaflets were inoculated as described by Lindhout and associates (1993).

TYLCV test. Agroinoculation was done using an Agrobacterium clone (Agroclone) with 1.8 copy of the TYLCV virus (Israel strain) cloned in $\mathrm{Ti}$ plasmid. To prepare the inoculum, Agroclone was first grown for $48 \mathrm{~h}$ at $28^{\circ} \mathrm{C}$ in Luria-Bertani medium with antibiotics (kanamycin and rifampicin, both at $100 \mu \mathrm{g} / \mathrm{ml}$ ); then, the culture was washed three times with water to remove culture media; and finally, the bacterium was dissolved in water $(30 \mathrm{ml}$ of culture was dissolved in $3 \mathrm{ml}$ of water). The plants were inoculated at the two- to three-trueleaf stage by infiltrating the inoculum using a syringe with needle. After inoculation, plants were grown in $16 \mathrm{~h}$ of light at $25^{\circ} \mathrm{C}$ and, after 14 to 20 days, were evaluated for TYLCV symptoms, including curling and yellowing of the young leaves and, in the extreme situation, stopping of growth. MM was used as the susceptible control and a breeding line carrying the Ty-1 gene originating from S. chilense LA1969 (Zamir et al. 1994) as the resistant control.

Nematode assay. Nematode (M. incognita, Laboratory of Nematology, Wageningen University) inoculation was performed on 2-month-old plants by injecting nematode suspension (second-stage juveniles 300 to $350 / \mathrm{ml}$ and $3 \mathrm{ml} / \mathrm{plant}$ ) into the sand around the roots. The second inoculation was followed 1 week later to ensure successful infection. Plants were grown in silver sand and maintained at $25^{\circ} \mathrm{C}$. One day before the inoculation, watering of the plants was stopped. Inoculated plants were watered from the tray under the pots for at least 1 week, in order to prevent washing nematodes away. The phloxine-B staining $(10 \mathrm{ng}$ per $100 \mathrm{ml}$ ) was used to visualize the nematode egg masses on the roots 60 days after inoculation. Plants were scored as resistant if the mean number of egg masses was less than $10 \%$ of the susceptible controls (Veremis et al. 1999). For nematode inoculation in VIGS experiments, each plant was inoculated once with 10,000 juveniles.

Powdery mildew assay. Wageningen isolate of $O$. neolycopersici was used (Bai et al. 2005). Fungal spores were washed from heavily infected tomato leaves and diluted to a concentration of $2.5 \times 10^{4}$ spores $/ \mathrm{ml}$. The inoculum was evenly sprayed on the 4-weak-old plants.

Cosegregation test. Two $\mathrm{BC}_{2} \mathrm{~S}_{1}$ populations (80 individuals each) segregating for $\mathrm{Ol}-4$ and $\mathrm{Ol}-6$ were tested with $\mathrm{O}$. neolycopersici and $M$. incognita. Plants were first tested with nematodes. Then, a cutting of each individual was made and challenged with $O$. neolycopersici. Tomato cultivars MM, Motelle (carrying the $\mathrm{Mi}-1$ gene), and Poldje (resistant to nematodes) as well as NIL-Ol-4 and NIL-Ol-6 were used as controls.

Aphid assay. Two different methods, performance assay and monitoring aphid feeding behavior by EPG, were used to compare response of different tomato lines to aphid (Macrosiphum euphorbiae). For the performance assay, two experiments were carried out on 6-week-old plants of MM, Motelle, NIL-Ol-4, and NIL-Ol-6. In the first one, a randomized block design was used with four replications (four plants per line in total). On each plant, a clip cage with 10 aphids was mounted on the fully expended youngest leaf. After 7 days, the number of aphids (adults and nymphs) was counted and then adults were removed. After another 7 days, aphids were counted again. In the second performance test, three plants per line were placed in one tray containing water to prevent the movement of aphids from one plant to another. Ten adults were placed on the abaxial leaf surface of the fully expanded young leaf of each plant. Data was taken 10 days after infestation by counting surviving adults and nymphs. For both experiments, the data was transformed to $(X+0.5)^{0.5}$ and then used for analysis of variance. Means of all four lines were compared by using Duncan's multiple range tests. For the EPG experiment, aphids were tested on young, almost fully expanded leaves of 6-weekold plants (four plants per line and two aphids per plant) and EPG recording was carried out for $10 \mathrm{~h}$ based on the standard procedure (Tjallingii 1988). By using the nonparametric Mann-Whitney test, data were analyzed separately for the first $4,6,8$, and total $10 \mathrm{~h}$ of the recordings. The analysis of the first $6 \mathrm{~h}$ provided the best distinction between genotypes and is presented here.

\section{VIGS.}

The TRV construct and method that have been successfully used to silence $\mathrm{Mi}-\mathrm{l}$ homologues in tomato (Li et al. 2006) and S. arcanum LA2157 (Jablonska et al. 2007) were used for silencing $\mathrm{Mi}-1$ homologues in NIL-Ol-4 and NIL-Ol-6. In brief, the TRV vector carrying a 300-bp fragment of the 3 ' end of Mi-1 cDNA was transformed into Agrobacterium tumefaciens GV3101. For VIGS with powdery mildew assay, agroinfiltration was done on cotyledons of 10-day-old seedlings using a needleless syringe and plants were maintained at 21 and $19^{\circ} \mathrm{C}$ (day and night, respectively). After 21 days, the plants were inoculated with tomato powdery mildew. For VIGS with nematode assay, agroinfiltration was done on 20-day-old seedlings using a needleless syringe and plants were maintained at 21 and $19^{\circ} \mathrm{C}$ (day and night, respectively). After 27 days, each plant was inoculated with 10,000 juveniles of $M$. incognita. Then, plants were maintained at 26 and $24^{\circ} \mathrm{C}$ (day and night, respectively) and evaluated for the presence or absence of egg masses 12 weeks after nematode inoculation. 


\section{Quantitative real-time PCR.}

Total RNA was extracted from the leaves of the Mi-silenced and TRV-inoculated plants by using the RNeasy Plant RNA extraction kit (Invitrogen). Total RNA (1 to $3 \mu \mathrm{g}$ ) was used for cDNA synthesis using the Superscritp III first-strand cDNA synthesis kit (Invitrogen). Real-time PCR was done by using iQ SYBR Green Supermix (Bio-Rad). The fold change of the target genes were normalized to elongation factor $1-\alpha$ (the internal control gene). Data was analyzed using the $2^{-\Delta \Delta C t}$ method (Livak and Schmittgen 2001) and reported as normalized fold expression.

\section{$M i-1$ gene first intron analysis.}

NIL-Ol-4 and NIL-Ol-6 genomic DNA was used as the template to amplify the first intron of $M i-1$ using primers $5^{\prime}$ TTCTCTAGCTAAACTTCAGCC-3' and 5'-TTTTCGTTTTT CCATGATTCTAC-3' (Jablonska et al. 2007), at $50^{\circ} \mathrm{C}$ as annealing temperature. The amplified fragments were gel-purified and cloned into pGEM-T-Easy vector (Promega Corp.). Three clones per fragment were sequenced. In NIL-Ol-4, we named these fragments Mint-O14S, Mint-Ol-4M, and Mint-Ol-4L, referring to short $(\mathrm{S})$, medium $(\mathrm{M})$, and long (L) fragments, respectively. In NIL-Ol-6, we only sequenced short and medium fragments, named Mint-Ol-6S1, Mint-Ol-6S2, and Mint-O16M (there are two short fragments in NIL-Ol-6). These sequences were deposited in GenBank under the following accession numbers: HQ259295 (Mint-Ol4S), HQ259296 (Mint-O14M), HQ259297 (Mint-O14L), HQ259298 (Mint-Ol6S1), HQ259299 (Mint-O16S2), and HQ259300 (Mint-Ol6M). Intron sequences from VFNT, Heinz 1706 (similar to MM in response to nematode and powdery mildew), S. arcanum LA1257, and LA392 were downloaded from GenBank. By using Mega4 software (Tamura et al. 2007), alignment and construction of a similarity tree were performed. The neighbor-joining method (Saitou and Nei 1987) was used to obtain the optimal tree with the sum of branch length $=1.99122550$. The distances were computed using the maximum composite likelihood method (Tamura et al. 2004) in the units of the number of base substitutions per site. All positions containing gaps were eliminated from the dataset (complete deletion option). The intron from potato Rpi-blb2 gene (a homologue of $M i-1$, referred to as Mint-Rpi-blb2) was used as the outgroup in this analysis.

\section{ACKNOWLEDGMENTS}

We thank J. van Bezooijen for his help in setting up the nematode assay, R. Huibers for valuable comments on this manuscript; and Syngenta Seeds BV and Monsanto Holland BV (previously Seminis Vegetable Seeds Europe and De Ruiter Seeds) for help in testing our near-isogenic lines with different pathogens. This research was jointly supported by the Dutch Technology Foundation (STW, grant no. WBI4835), Dutch breeding companies, and Wageningen UR Plant Breeding. Also, this work is matching to a project financed by the Centre for BioSystems Genomics (CBSG), which is part of the Netherlands Genomics Initiative/Netherlands Organization for Scientific Research.

\section{LITERATURE CITED}

Ammiraju, J., Veremis, J., Huang, X., Roberts, P., and Kaloshian, I. 2003. The heat-stable root-knot nematode resistance gene $\mathrm{Mi}-9$ from $\mathrm{Lyc}$ opersicon peruvianum is localized on the short arm of chromosome 6 . Theor. Appl. Genet. 106:478-484.

Bai, Y., van der Hulst, R., Bonnema, G., Marcel, T., Meijer-Dekens, F., Niks, R., and Lindhout, P. 2005. Tomato defense to Oidium neolycopersici: Dominant $\mathrm{Ol}$ genes confer isolate-dependent resistance via a different mechanism than recessive ol-2. Mol. Plant-Microbe Interact. 18:354-362.

Bisgrove, S., Simonich, M., Smith, N., Sattler, A., and Innes, R. 1994. A disease resistance gene in Arabidopsis with specificity for two different pathogen avirulence genes. Plant Cell 6:927.
Dangl, J. L. and Jones J. D. G. 2001. Plant pathogens and integrated defence responses to infection. Nature 411:826-833.

de Ilarduya, O., Xie, Q., and Kaloshian, I. 2003. Aphid-induced defense responses in $\mathrm{Mi}$-1-mediated compatible and incompatible tomato interactions. Mol. Plant-Microbe Interact. 16:699-708.

Dickinson, M. J., Jones, D. A., and Jones, J. D. G. 1993. Close linkage between the $C f-2 / C f-5$ and $M i$ resistance loci in tomato. Mol. Plant-Microbe Interact. 6:341-347.

Dixon, M., Hatzixanthis, K., Jones, D., Harrison, K., and Jones, J. 1998. The tomato $C f-5$ disease resistance gene and six homologs show pronounced allelic variation in leucine-rich repeat copy number. Plant Cell 10:1915.

Dixon, M. S., Jones, D. A., Keddie, J. S., Thomas, C. M., Harrison, K. and Jones, J. D. G. 1996. The tomato $C f$-2 disease resistance locus comprises two functional genes encoding leucine-rich repeat proteins. Cell 84:451-459.

Dropkin, V., Helgeson, J., and Upper, C. 1969. The hypersensitivity reaction of tomatoes resistant to Meloidogyne incognita: Reversal by cytokinins. J. Nematol. 1:55.

Ellis, J., Lawrence, G., Luck, J., and Dodds, P. 1999. Identification of regions in alleles of the flax rust resistance gene $L$ that determine differences in gene-for-gene specificity. Plant Cell 11:495.

Glazebrook, J. 2005. Contrasting mechanisms of defense against biotrophic and necrotrophic pathogens. Annu. Rev. Phytopathol. 43:205-227.

Ho, J. Y., Weide, R., Ma, H. M., Vanwordragen, M. F., Lambert, K. N., Koornneef, M., Zabel, P., and Williamson, V. M. 1992. The root-knot nematode resistance gene $(\mathrm{Mi})$ in tomato-construction of a molecular linkage map and identification of dominant cDNA markers in resistant genotypes. Plant J. 2:971-982.

Jablonska, B., Ammiraju, J. S. S., Bhattarai, K. K., Mantelin, S., de Ilarduya, O. M., Roberts, P. A., and Kaloshian, I. 2007. The Mi-9 gene from Solanum arcanum conferring heat-stable resistance to root-knot nematodes is a homolog of Mi-1. Plant Physiol. 143:1044-1054.

Kaloshian, I., Yaghoobi, J., Liharska, T., Hontelez, J., Hanson, D., Hogan, P., Jesse, T., Wijbrandi, J., Simons, G., Vos, P., Zabel, P., and Williamson, V. M. 1998. Genetic and physical localization of the rootknot nematode resistance locus $M i$ in tomato. Mol. Gen. Genet. 257:376-385

Kaloshian, I., Kinsey, M. G., Williamson, V. M., and Ullman, D. E. 2000. $M i$-mediated resistance against the potato aphid Macrosiphum euphorbiae (Hemiptera: Aphididae) limits sieve element ingestion. Environ. Entomol. 29:690-695.

Kim, Y., Lin, N., and Martin, G. 2002. Two distinct Pseudomonas effector proteins interact with the Pto kinase and activate plant immunity. Cell 109:589-598.

Li, C., Bonnema, G., Che, D., Dong, L., Lindhout, P., Visser, R., and Bai, Y. 2007. Biochemical and molecular mechanisms involved in monogenic resistance responses to tomato powdery mildew. Mol. Plant-Microbe Interact. 20:1161-1172.

Li, Q., Xie, Q., Smith-Becker, J., Navarre, D., and Kaloshian, I. 2006. Mil-mediated aphid resistance involves salicylic acid and mitogen-activated protein kinase signaling cascades. Mol. Plant-Microbe Interact. 19:655-664.

Lindhout, P., Pet, G., and Beek, H. 1993. Screening wild Lycopersicon species for resistance to powdery mildew (Oidium lycopersicum). Euphytica 72:43-49.

Livak, K., and Schmittgen, T. 2001. Analysis of relative gene expression data using real-time quantitative PCR and the 2-[delta][delta] CT method. Methods 25:402-408.

Michelmore, R., and Meyers, B. 1998. Clusters of resistance genes in plants evolve by divergent selection and a birth-and-death process. Genome Res. 8:1113.

Milligan, S. B., Bodeau, J., Yaghoobi, J., Kaloshian, I., Zabel, P., and Williamson, V. M. 1998. The root knot nematode resistance gene $M i$ from tomato is a member of the leucine zipper, nucleotide binding, leucine-rich repeat family of plant genes. Plant Cell 10:1307-1319.

Narusaka, M., Shirasu, K., Noutoshi, Y., Kubo, Y., Shiraishi, T., Iwabuchi, M., and Narusaka, Y. 2009. RRS1 and RPS4 provide a dual resistance gene system against fungal and bacterial pathogens. Plant $\mathrm{J}$. 60:218-226.

Nimchuk, Z., Eulgem, T., Holt, B. E., and Dangl, J. L. 2003. Recognition and response in the plant immune system. Annu. Rev. Genet. 37:579609.

Nombela, G., Williamson, V. M., and Muniz, M. 2003. The root-knot nematode resistance gene $\mathrm{Mi}-1.2$ of tomato is responsible for resistance against the whitefly Bemisia tabaci. Mol. Plant-Microbe Interact. 16:645-649.

Roberts, P., and Thomason, I. 1986. Variability in reproduction of isolates of Meloidogyne incognita and Meloidogyne javanica on resistant tomato genotypes. Plant Dis. 70:547-551. 
Rossi, M., Goggin, F. L., Milligan, S. B., Kaloshian, I., Ullman, D. E., and Williamson, V. M. 1998. The nematode resistance gene $\mathrm{Mi}$ of tomato confers resistance against the potato aphid. Proc. Natl. Acad. Sci. U.S.A. 95:9750-9754.

Saitou, N., and Nei, M. 1987. The neighbor-joining method: A new method for reconstructing phylogenetic trees. Mol. Biol. Evol. 4:406.

Seah, S., Yaghoobi, J., Rossi, M., Gleason, C., and Williamson, V. 2004 The nematode-resistance gene, $M i-1$, is associated with an inverted chromosomal segment in susceptible compared to resistant tomato. Theor. Appl. Genet. 108:1635-1642.

Seah, S., Telleen, A. C., and Williamson, V. M. 2007. Introgressed and endogenous $\mathrm{Mi}-\mathrm{l}$ gene clusters in tomato differ by complex rearrangements in flanking sequences and show sequence exchange and diversifying selection among homologues. Theor. Appl. Genet. 114:12891302.

Staskawicz, B. J., Ausubel, F. M., Baker, B. J., Ellis, J. G., and Jones, J. D. G. 1995. Molecular genetics of plant disease resistance. Science 268:661-667.

Tamura, K., Nei, M., and Kumar, S. 2004. Prospects for inferring very large phylogenies by using the neighbor-joining method. Proc. Natl. Acad. Sci. U.S.A.101:11030.

Tamura, K., Dudley, J., Nei, M., and Kumar, S. 2007. MEGA4: Molecular evolutionary genetics analysis (MEGA) software version 4.0. Mol. Biol. Evol. 24:1596.

Tjallingii, W. 1988. Electrical recording of stylet penetration activities. Pages 95-107 in: Aphids, Their Biology, Natural Enemies and Control, Vol. B. A. K. Minks and P. Harrewijn, eds. Elsevier Science Publishers, Amsterdam.

van der Vossen, E. A. G., van der Voort, J., Kanyuka, K., Bendahmane, A., Sandbrink, H., Baulcombe, D. C., Bakker, J., Stiekema, W. J., and Klein-Lankhorst, R. M. 2000. Homologues of a single resistance-gene cluster in potato confer resistance to distinct pathogens: A virus and a nematode. Plant J. 23:567-576.

Veremis, J., Van Heusden, A., and Roberts, P. 1999. Mapping a novel heatstable resistance to Meloidogyne in Lycopersicon peruvianum. Theor Appl. Genet. 98:274-280.

Vossen, E., Gros, J., Sikkema, A., Muskens, M., Wouters, D., Wolters, P., Pereira, A., and Allefs, S. 2005. The Rpi-blb2 gene from Solanum bulbocastanum is an $\mathrm{Mi}-1$ gene homolog conferring broad-spectrum late blight resistance in potato. Plant J. 44:208-222.

Wang, Y., Bao, Z., Zhu, Y., and Hua, J. 2009. Analysis of temperature modulation of plant defense against biotrophic microbes. Mol. PlantMicrobe Interact. 22:498-506.

Whitham, S., McCormick, S., and Baker, B. 1996. The $N$ gene of tobacco confers resistance to tobacco mosaic virus in transgenic tomato. Proc. Natl. Acad. Sci. U.S.A.93:8776.

Williamson, V. M., and Kumar, A. 2006. Nematode resistance in plants: The battle underground. Trends Genet. 22:396-403.

Yang, S., and Hua, J. 2004. A haplotype-specific resistance gene regulated by BONZAI1 mediates temperature-dependent growth control in Arabidopsis. Plant Cell 16:1060.

Zamir, D., Michelson, I., Zakay, Y., Navot, N., Zeidan, N., Sarfatti, M., Eshed, Y., Harel, E., Pleban, T., van-Oss, H., Kedar, N., Rabinowitch, H. D., and Czosnek, H. 1994. Mapping and introgression of a tomato yellow leaf curl virus tolerance gene, Ty-1. Theor. Appl. Genet. 88:141-146.

Zhang, L., Khan, A., Nino-Liu, D., and Foolad, M. 2002. A molecular linkage map of tomato displaying chromosomal locations of resistance gene analogs based on a Lycopersicon esculentum $\times$ Lycopersicon hirsutum cross. Genome 45:133-146.

\section{AUTHOR-RECOMMENDED INTERNET RESOURCE}

Sol Genomics network: solgenomics.net 